\title{
NOVÉ SBÍRKOVÉ AKVIZICE V KNIHOVNĚ NÁRODNÍHO MUZEA V ROCE 2021
}

\author{
Pavel Muchka (Praha)
}

I přes nepř́znivou epidemiologickou situaci se fondy Knihovny Národního muzea v roce 2021 výrazně rozrostly, a to výlučně v oddělení knižní kultury. Jedná se v převážné většině o kolekce moderních a současných autorských štočků a exlibris, mezi nimiž vynikají grafiky z mezinárodní exlibristické soutěže.

Od Jana Langhammera z Plzně, dlouholetého aktivního člena Spolku sběratelů a prátel exlibris, byly zakoupeny soupisy a soubory exlibris Karla Kinského (1901-1969) z let 1926 až 1969. V publikacích jsou vloženy neznámé originální dopisy Karla Kinského sběrateli Ing. Otakaru Hradečnému dokumentující grafikovu činnost.

Doplněn byl také fond Ilustrací nákupem 93 ilustrací Václava Fialy (1896-1980) ke knize Eduarda Petišky Staré recké báje a pověsti, která vyšla ve Státním nakladatelství dětské knihy v roce 1958. Nabídku do sbírek předložila Jana Kotalíková z Prahy, dcera ilustrátora, zaměřeného na ilustrování děl pro děti a mládež. V oddělení knižní kultury se nacházejí již 3 ilustrace k této knize (Božstvo, Perseus utínající hlavu Meduse a Achilles vláčející Hektorovu mrtvolu za svým vozem). Dojde zde tak ke kompletaci celého ilustračního souboru a ucelení zastoupení ilustrační tvorby Václava Fialy v muzejní knihovně.

Dále byl zakoupen soubor 13 linorytových štočků Pavla Piekara z roku 2021 pro barevný soutisk - grafický list Josef Váchal s podepsaným nátiskem a př́pravnou kresbou. Rovněž do fondu Štočků byl získán od Jana Proška z Prahy ocelorytový štoček s motivem svatého obrázku Panny Marie Vranovské a s ilustrovanými česko-německými rýmy z poloviny 19. století, dobově používanými k dekorování obalů

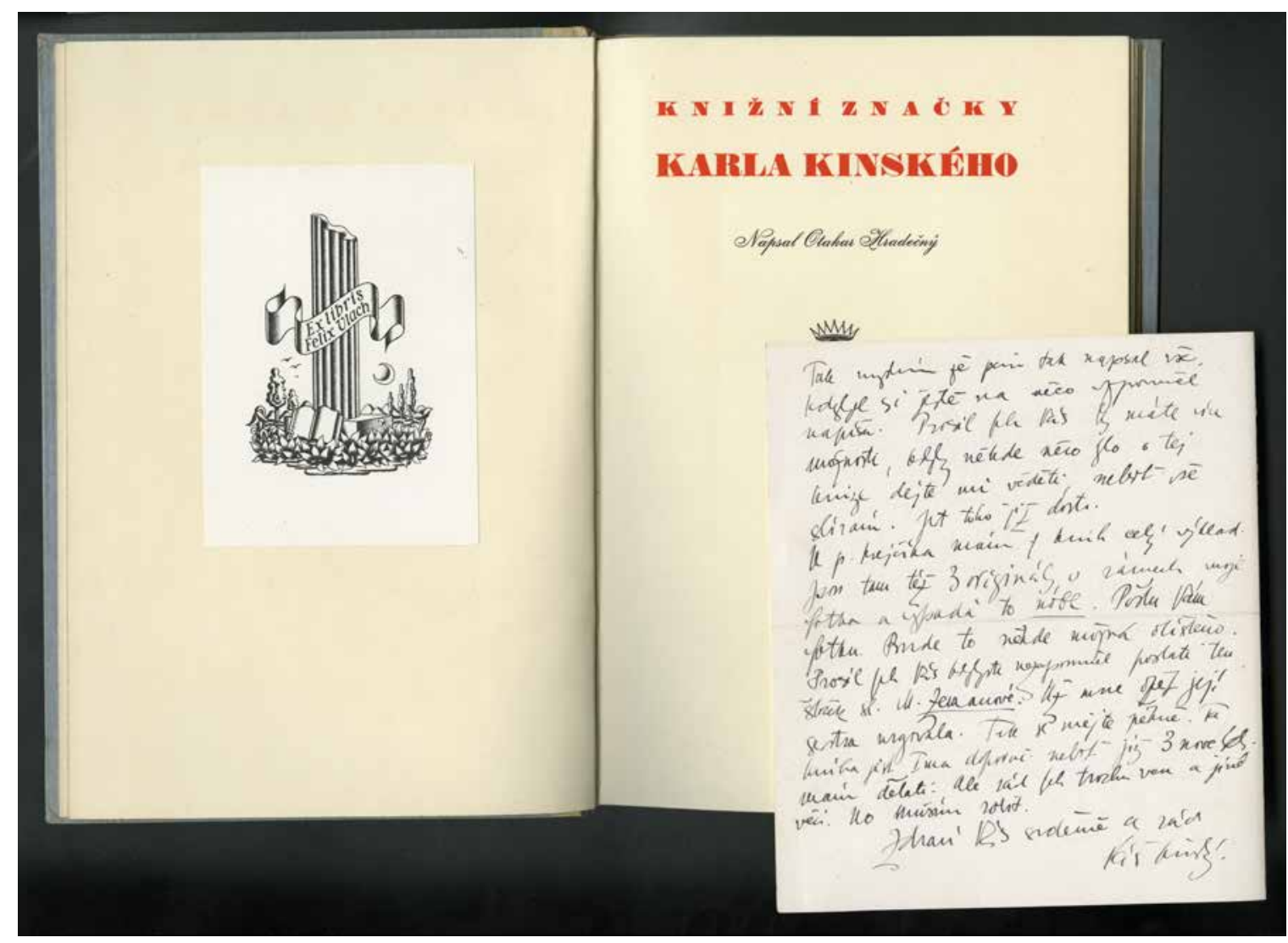

Obr. 1. Soupis knižních značek Karla Kinského z roku 1940 v knižní vazbě Jendy Rajmana. Přiložen dopis K. Kinského z roku 1940. 

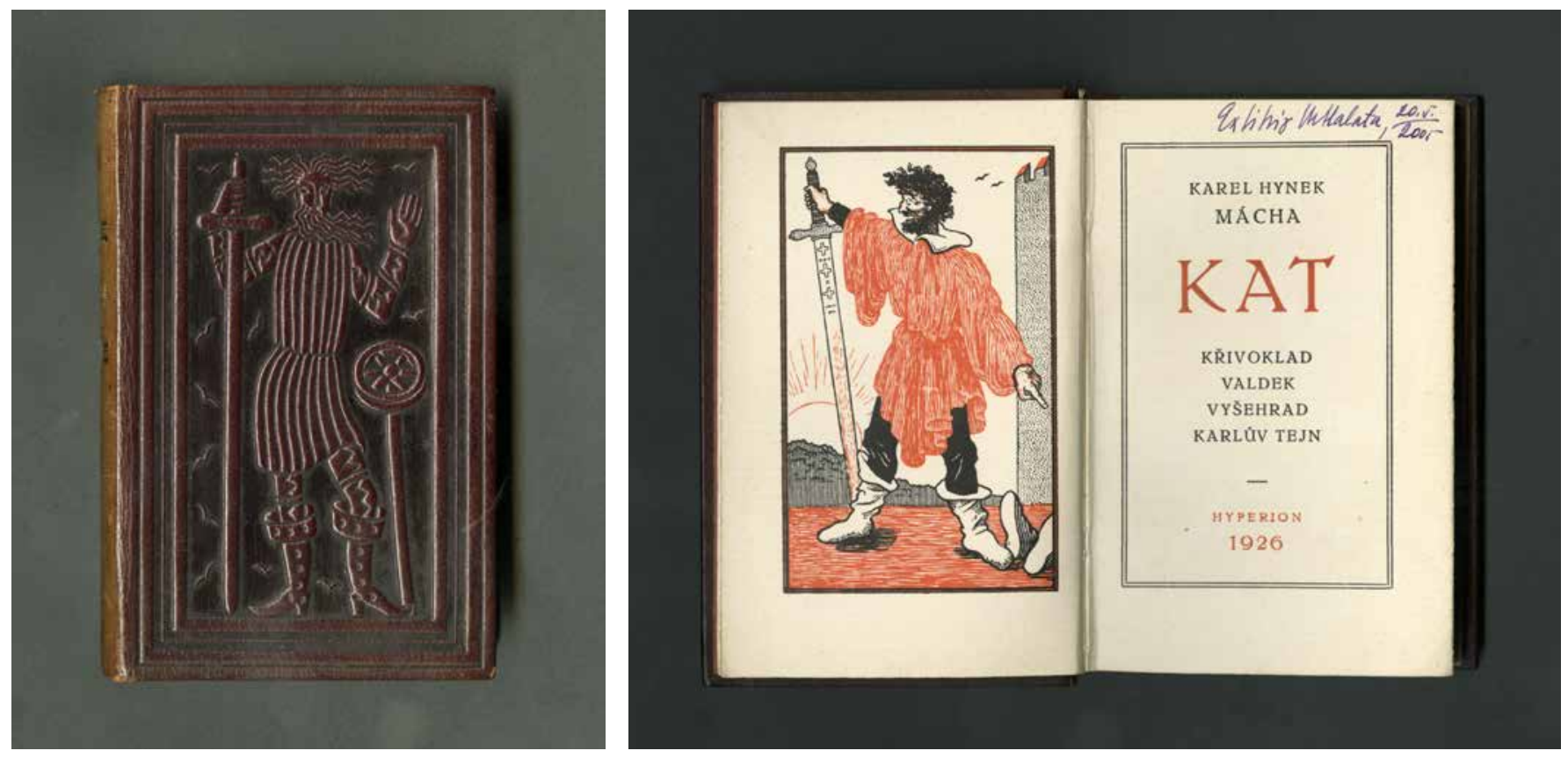

Obr. 2a a 2b. Bibliofilský tisk z knihovny sběratele a bibliofila Josefa Jeřábka v knižní vazbě Antonína Tvrdého - K. H. Mácha: Kat. Erna Janská, edice Hyperion, Nový Jičín, 1926.

potravinářského zboží. Předmět je unikátním dokladem tiskařské a grafické práce 19. století. Nabízející štoček získal prostřednictvím internetového portálu Aukro.

Rozsahem i obsahem zcela mimořádné jsou doklady z provozu dílny knihaře Jendy Rajmana (1892-1965) v Rožd'alovicích v celkovém počtu 1034 kusů, zakoupené od Rajmanových potomků. Nacházejí se zde zatím ve sbírkách nezastoupené vzorníky secesních vazeb a škrobových papírů. Spolupráci s výtvarníky při realizaci knižních vazeb dokládají originální návrhy k nim v počtu 229 kusů.
Zajímavá je početná sbírka předsádkových papírů (mramorované, japonské, krčené, lihové, strukturované), které jsou nepostradatelným pomocníkem při knihařově práci. Představu o činnosti Rajmanovy dílny pak demonstrují zakázkové sešity z let 1944 až 1951 a zakázková korespondence s nakladatelstvími z let 1946 až 1957.

Ze získaných darů je nejhodnotnější soubor 389 exlibris z mezinárodní exlibristické soutěže, která se konala u př́ležitosti mezinárodního kongresu FISAE v Praze roku 2018, věnovaný Spolkem sběratelů a přátel exlibris. Jedná

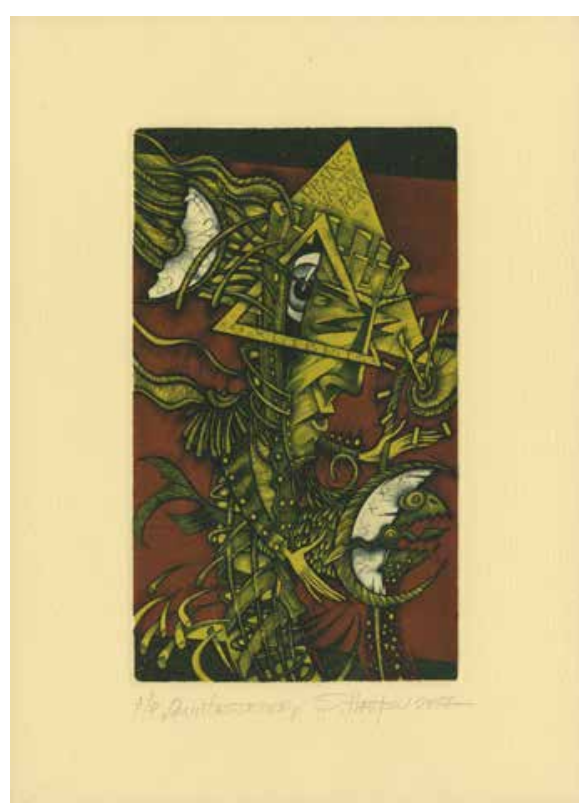

Obr. 3. Exlibris z kongresové výstavní kolekce FISAE 2018. Sergiy Hrapov: exlibris s názvem Quintessence pro Franze van der Veena, lept, akvatinta a mezzotinta, 2018 (Čína).

(Ukrajina). Nominováno na ocenění.

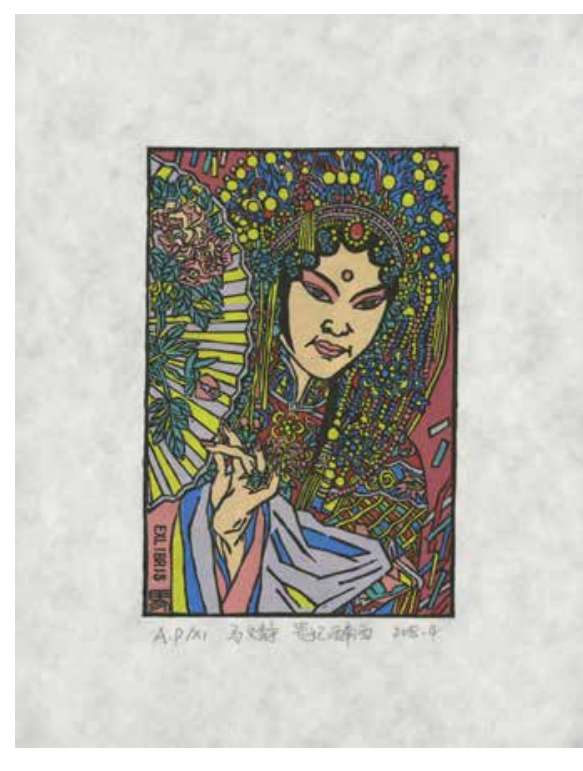

Obr. 4. Exlibris z kongresové výstavní kolekce FISAE 2018. Ma Wenjing: exlibris s názvem Opilá krása, barevný dřevořez, 2018

Opila krása, barevný drevorez, 2018 (1)

.

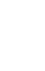




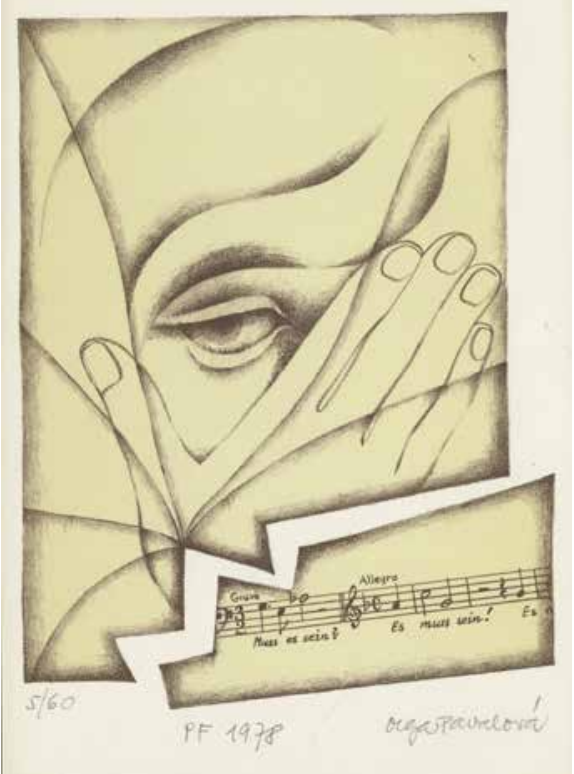

Obr. 6. Litografická novoročenka grafičky a ilustrátorky Olgy Pavalové na rok 1978.

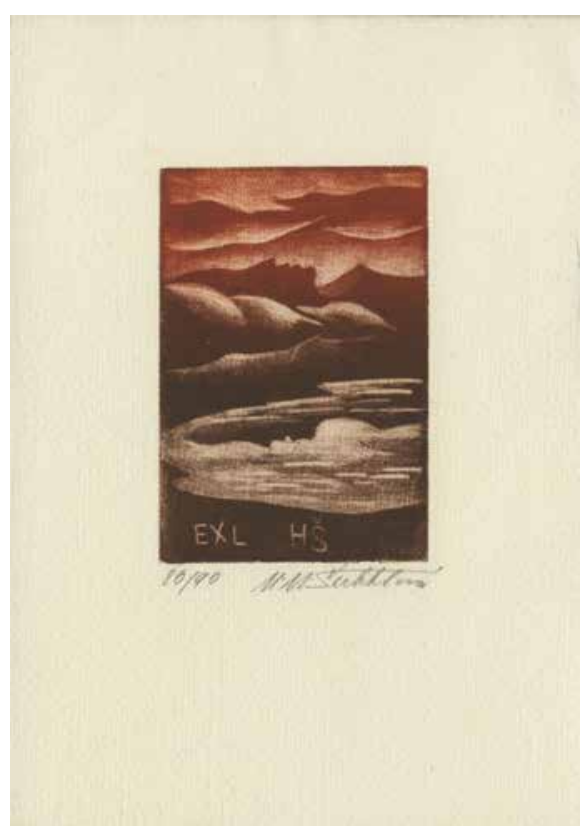

Obr. 7. Autorské exlibris grafičky M. Šechtlové pro H. Š. Moře zapomnění, barevná mezzotinta, 1994.

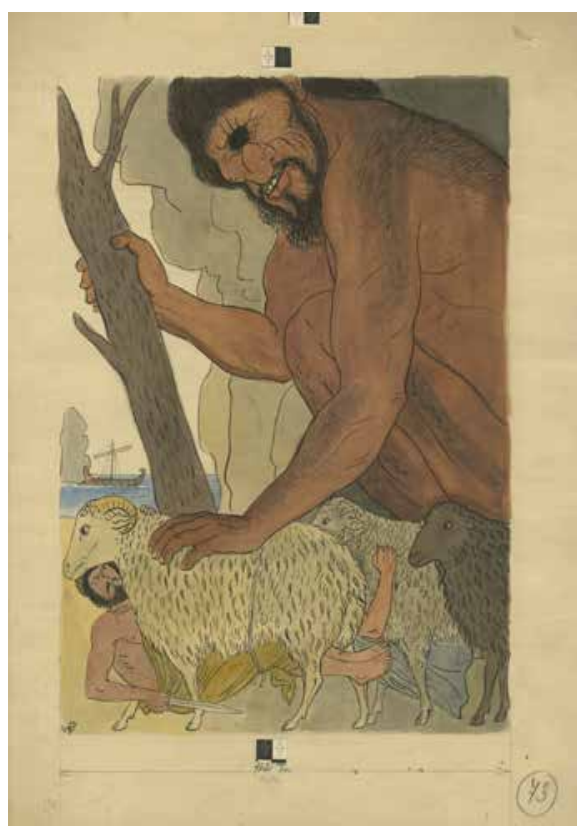

Obr. 8. Originální ilustrace Václava Fialy ke knize Eduarda Petišky Staré řecké báje a pověsti, kresba tuší, akvarel, 1958.

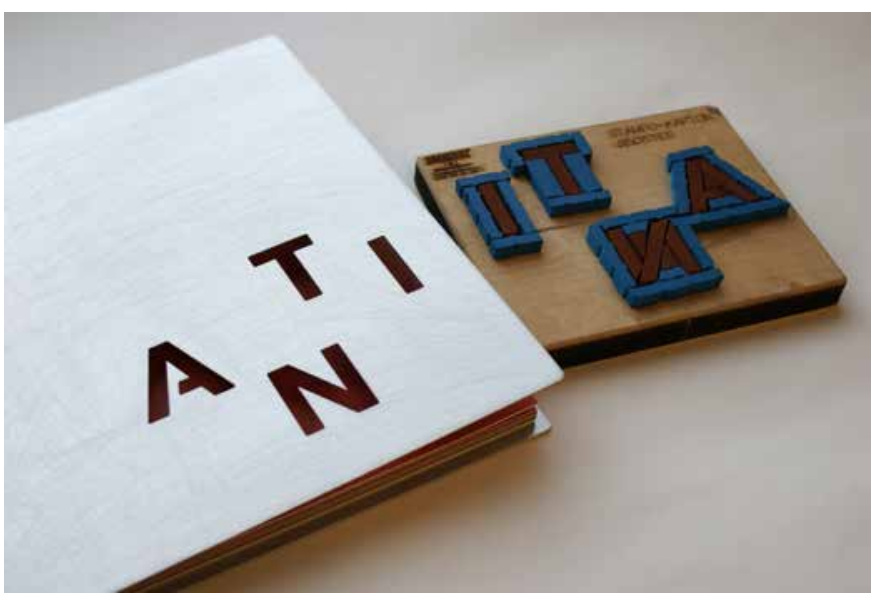

Obr. 9. Maketa knihy Václava Havla Antikódy (Praha, Teapot, 2015) a raznice pro výseky obálky a stránek; grafický design Johana Kratochvílová.

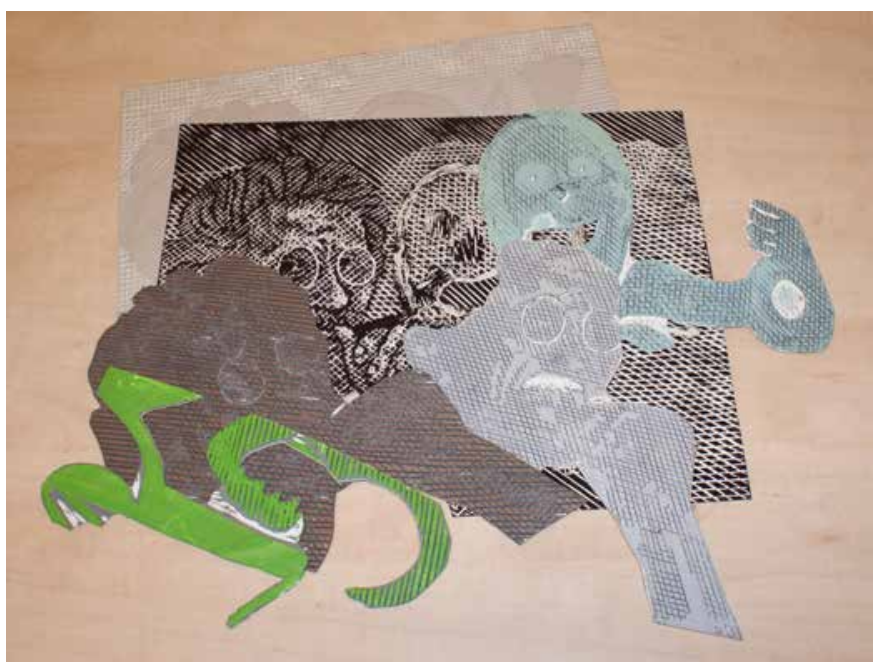

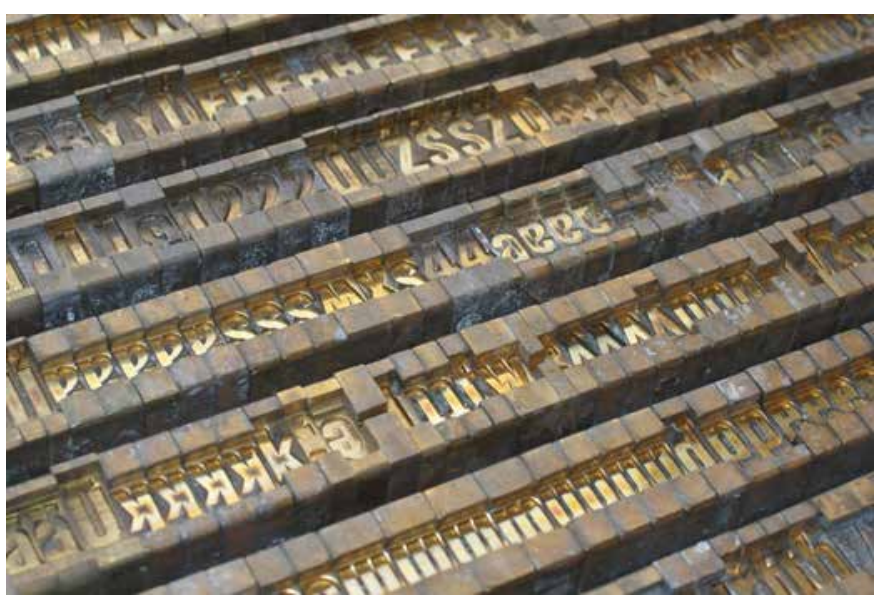

Obr. 10. Sady matric na výrobu liter k odlévacímu stroji Ludlow Typograph.

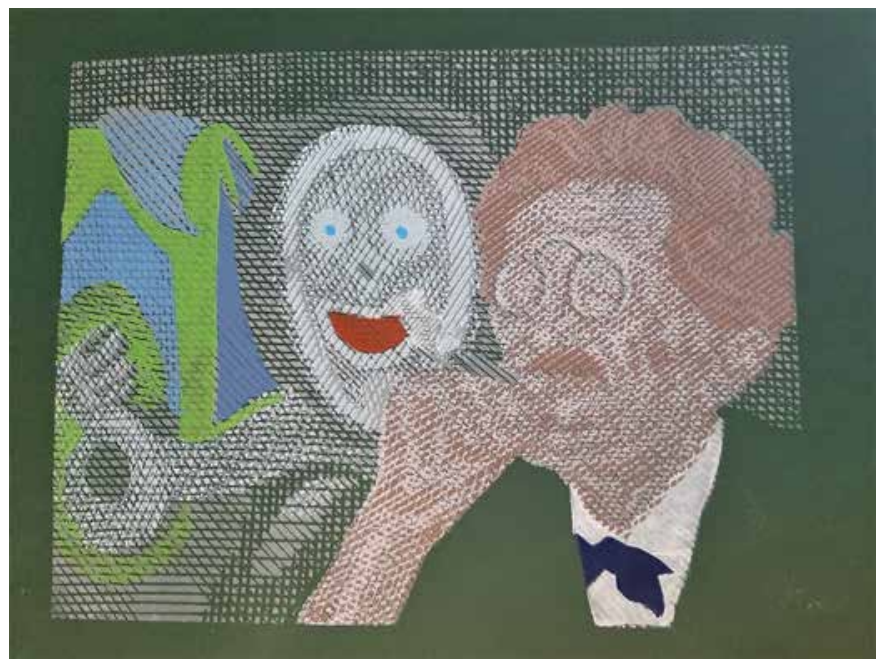

Obr. 11a a 11b. Soubor autorských linorytových štočků Pavla Piekara pro barevný soutisk grafického listu Josef Váchal, s nátiskem, 2021. 


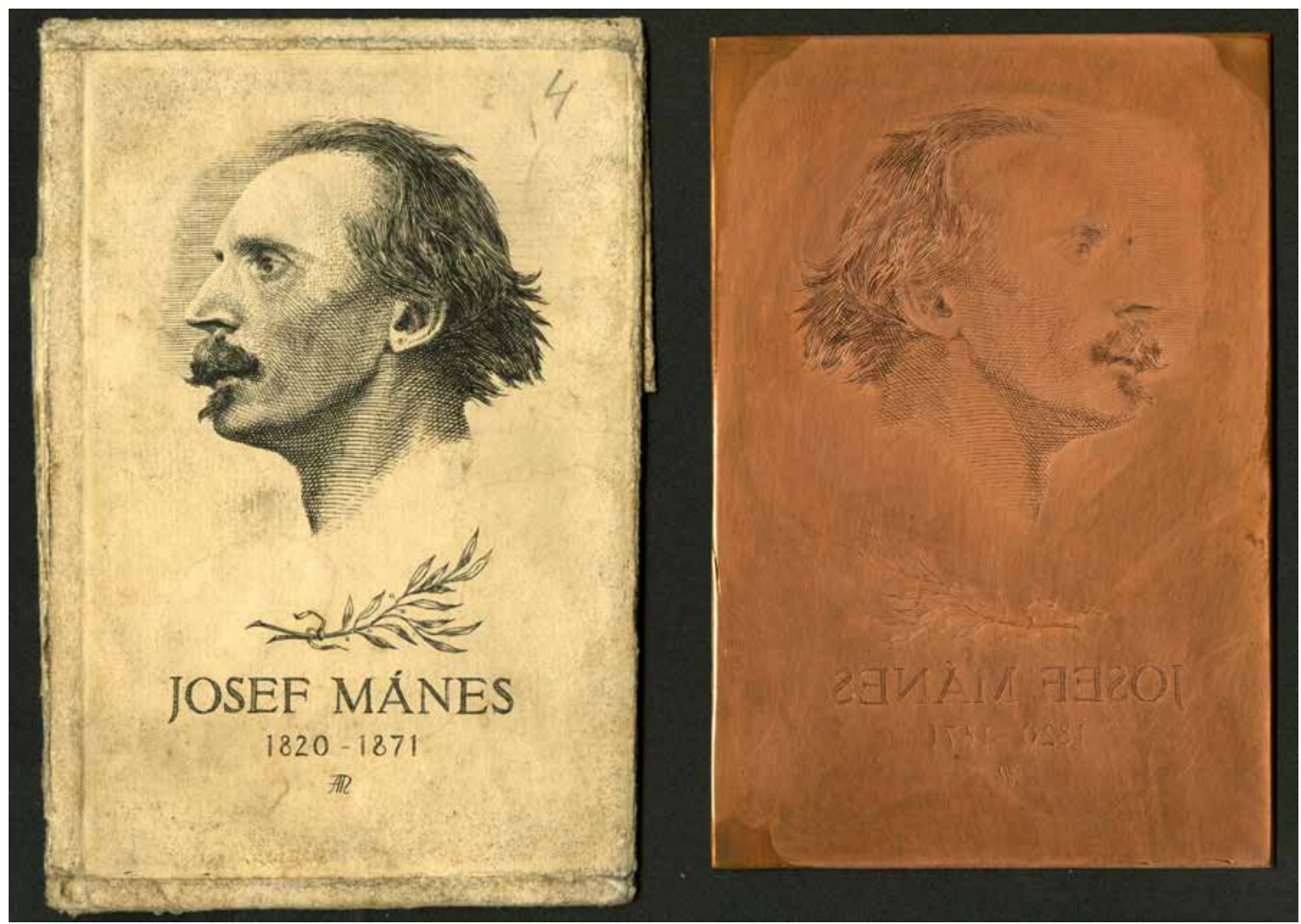

Obr. 12. Rytá kovová matrice Arno Naumana pro tisk grafického listu s portrétem Josefa Mánesa, s nátiskem, 1935.

se o významný srovnávací materiál pro současnou českou tvorbu exlibris, který je možno využít badatelsky i výstavně. Zajímavý je i soubor 52 autorských exlibris a př́ležitostné grafiky z let 1974 až 2006 Marie Michaely Šechtlové z Tábora, jejíž dílo není dosud ve fondu Exlibris Knihovny NM významně zastoupeno. Podobný případ je také kolekce exlibris a novoročenek Marie Jančákové (1887-1959) a pozvánek, novoročenek a návrhů na př́iležitostnou grafiku Olgy Pavalové (1930-1998), kterou věnovala do sbírek oddělení knižní kultury dcera grafičky, Alexandra Pavalová.

Zdrojem pro studium moderní knižní kultury jsou darované dokumenty přední znalkyně moderní knižní ilustrace Blanky Stehlíkové, kde je možné najít i českou a zahraniční korespondenci s významnými představiteli kultury - spisovatelé a literární historici, historici umění, výtvarníci, nakladatelství a kulturní instituce. Celkem se jedná o 1975 položek. Zvláště početné jsou zde složky k tvorbě Josefa Lady, Josefa Čapka, Květy Pacovské, Petra Dillingera či Vladimíra Komárka.

Fond Hmotných památek se rozšśřil o soubor maket, zkušebních nátisků, matric a vzorků materiálů k pěti bibliofiliím (Antikódy V. Havla; Proměna F. Kafky; Záhořovo lože K. J. Erbena; Vzpoura sládků V. Effenbergera a Krotitelé šneků P. H. Camiho) z produkce nakladatelství Teapot $\mathrm{z}$ let 2015 až 2020, které se výlučně zaměřuje na produkci exkluzivních bibliofilií. Soubor představuje cennou ukázku procesu vzniku současných bibliofilských tisků. Od Lubomíra Krupky z Úval u Prahy pochází nabídka daru 23 sad matric na výrobu liter k odlévacímu stroji Ludlow Typograph (patková a bezpatková písma), zachovaných v původní adjustaci. Od něho byly také získány pro fond Štočků 3 linoryty

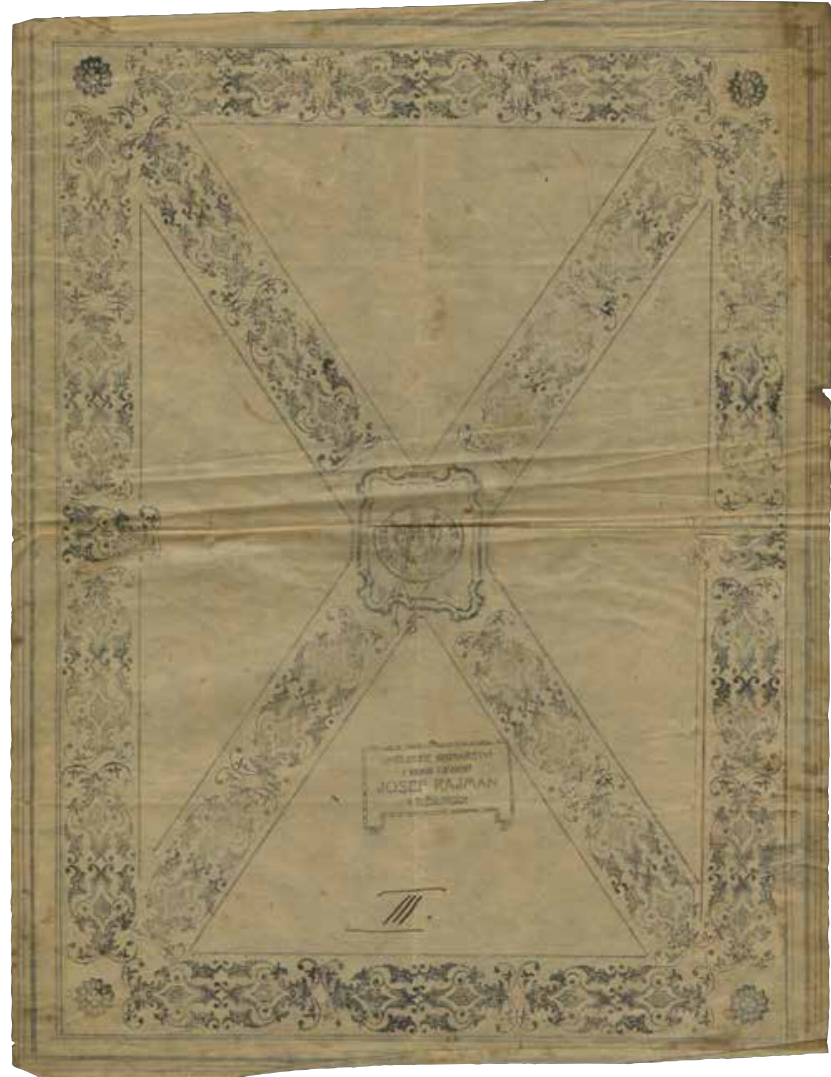

Obr. 13. Originální návrh na knižní vazbu z období činnosti dílny uměleckého knihaře Jendy Rajmana v Rožd’alovicích.

nadějné grafičky Evy Čapkové ke knize Františka Langera Vnitřní zrak, které se objevily jako ilustrační doprovod 
bibliofilie z produkce Ateliéru Krupka v roce 2017. Fond Štočků se ale v roce 2021 rozrostl především díky daru Sdružení českých umělců grafiků Hollar, od něhož získala Knihovna Národního muzea 284 štočků z pozůstalosti významného grafika Arno Naumana (1887-1959), které byly dočasně uloženy ve sklepení Šternberského paláce. Obsahují v naprosté většině Naumanovy dřevorytové štočky, matrice $\mathrm{k}$ leptům, mezzotintě, suché jehle a rytině, realizované jako ilustrační doprovod (např́íklad k Babičce Boženy Němcové z roku 1948 nebo Zlatému věku Rudolfa Medka z roku 1929), prrípadně k volné a užité grafice (exlibris, novoročenky) především z dvacátých a třicátých let 20 . století.
Vedle současné české bibliofilské produkce se knižní fond Bibliofilie doplnil o kolekci tisků z pozůstalosti sběratele a bibliofila Josefa Jeřábka (1877-1957) a bibliofilií archiváře Martina Halaty (tisky typografa Břetislava Štorma) $\mathrm{v}$ celkovém počtu 26 kusů.

\author{
Pavel Muchka \\ Knihovna Národního muzea \\ oddělení knižní kultury \\ Vinohradská 1 \\ 11000 Praha 1
}

